\title{
Climate Change Adaptation and Vulnerability: A Case of Rain Dependent Small-Holder Farmers in Selected Districts in Zambia
}

\author{
Cuthbert Casey Makondo', Kenneth Chola², Blesswell Moonga ${ }^{3}$ \\ ${ }^{1}$ Environmental Engineering Department, Copperbelt University, Kitwe, Zambia \\ ${ }^{2}$ United Nations World Food Programme, Lusaka, Zambia \\ ${ }^{3}$ Ministry of Agriculture and Livestock, Ndola, Zambia \\ Email: simplyCuthbert@live.co.uk
}

Received 21 August 2014; revised 18 September 2014; accepted 12 October 2014

Copyright (C) 2014 by authors and Scientific Research Publishing Inc.

This work is licensed under the Creative Commons Attribution International License (CC BY). http://creativecommons.org/licenses/by/4.0/

(c) (i) Open Access

\section{Abstract}

Food crop production by small-holder farmers in Africa is particularly vulnerable to climate change, given high dependence on rainfall coupled with limited adaptive capacity. In Zambia, smallholder farmers contribute about $\mathbf{7 9 \%}$ of national stable food requirements particularly maize. This paper attempted to establish levels of food security in each of the three agro-ecological zones of Zambia, and evaluated the current adaptive measures of rain dependent small-holder farmers against climate change risks. The challenges farmers are facing in adapting to the change risks were identified and livelihood vulnerability assessed. The findings indicate that rain dependent small-holder farmers in Zambia are highly vulnerable to weather related shocks which impact greatly on their food production; and that the levels of vulnerability vary across gender and per agro-ecological zone. After the evaluation of scenarios including staple food crop yields (maize), the authors conclude that most rain-fed small-holder farmers in Zambia (about 70\%) are facing considerable hardships in adapting to the changing climate, which in turn, undermines their contribution to food security. While efforts by government have been made to assist farmers towards climate change adaptation, there still remains many challenges to achieve the desired outcomes. Most farmers (66\%) are unable to afford certain alternatives, such as those of agro-forestry or conservation. Difficulties in accessing markets, poor road infrastructure, fluctuating market prices, high costs and late deliveries of farming in-puts were found to be among the major challenges that farmers are facing in Zambia. There are also no systematic early warning systems in place against natural hazards and disasters. This makes farming a difficult undertaking in Zambia. 


\section{Keywords}

\section{Vulnerability, Food Security, Livelihood, Adaptation, Climate Change}

\section{Introduction}

Zambia is a landlocked, sparsely populated sub-Saharan country with 13.8 million people [1]. It is still largely rural. Prone to both droughts and floods, it also has one of the highest HIV/AIDS prevalence rates in the subSahara. As observed by [2] such challenges as HIV/AIDS have increased vulnerability and depleted the assets of farmers leaving many, facing hunger. Confounded with HIV/AIDS, climate change i.e. variabilities in the climatic conditions (rainfall and temperature) is expected to have intense severity on food crop production in Zambia and much of Southern Africa making it more difficult to grow crops, raise animals, and catch fish or do business using conventional methods [3] [4]. According to [5], Zambia was ranked at number 17 out of the top 20 countries in the 2008 rankings that will experience severe impacts from extreme weather events in 2015. Similarly, the Fourth Assessment Report of the Intergovernmental Panel on Climate Change (which draws upon hundreds of studies portraying the immense differentiation within the continent's sub-regions and sectors) points to significant current and future vulnerabilities in food production and ecosystems among others, particularly in developing nations [6]. The United Nations General Assembly reached a similar conclusion in 2012 following the Rio +20 United Nations Conference on Sustainable Development [7]. Today, the UN emphasizes that climate change is undermining the achievement of Millennium Development Goals, especially in developing countries [8].

In Zambia, agriculture accounts for more than $70 \%$ of all employment [2]. However, due to poor utilization of land resources and poor farming methods, farmers have severely degraded the soil, making it difficult for many rain dependent small-holder farmers to raise agricultural production above subsistence levels. Conversely, increasing costs of fertilizers, and other agricultural inputs such as seed, and rising transportation costs have also contributed greatly to making food crop production more expensive. Consequently, with poverty levels currently standing at about $60.5 \%$, more effort is required in Zambia to lower poverty to acceptable levels. Thus, although agriculture in Zambia contributes only about 3\% to the GDP, it has great potential for reducing poverty through employment the sector creates, especially that more than $50 \%$ of Zambia's total population lives in rural areas, and is dependent entirely on rain-fed agriculture [1]. Under Zambia's National Long-term Vision 2030, the Government of the Republic of Zambia has mainstreamed agriculture to the main development agenda as one of the key means for eradicating poverty, especially in rural communities. However, if the country is to remain food secure, it is important that efforts aimed at helping small-holder rain dependent farmers adapt to climate change are scaled up. Rural livelihood in Zambia is entirely dependent directly on ecosystem services for survival, e.g. rainfall for food production; rivers for drinking water and source of protein; forests for construction materials, energy and medicine. For this reason, people tend to settle in marginal lands which are prone to environmental disasters such as floods and droughts. Consequently, their livelihoods are most likely to be affected by even slight changes in climatic conditions [9].

Conversely, because of gender-based inequalities in accessing critical livelihood assets such as land, credit, technology, information, and markets, women tend to be the most exposed to climate change risks, confounding the existing challenges in building resilience. The findings of this enquiry are consistent with this argument. Changes in climatic conditions may possibly be the surest way of scaling up massive sufferings from hunger, malnutrition, disease and extreme poverty in rural communities, because these people generally lack the necessary adaptive capacities to cope with climate change [6] [10].

\section{Agricultural Extension Programs}

Many agricultural programmes have been carried out in Zambia as part of the Green Revolution approach to food security, both by the Government of the Republic of Zambia (GRZ), Non-Governmental Organization (NGO), and international donor aid organizations. As part of the Green Revolution, GRZ introduced numerous programmes starting from an establishment of Lima Bank to manage agricultural loans; to curriculum review at basic school level to include agricultural science, and later followed by the establishments of Agricultural Colleges in all the 9 provinces at the time. Others include the establishment of the National Agricultural Information 
Services (NAIS) which is a specialized information wing of the Ministry of Agriculture and Livestock, whose main role is that of supporting the extension services of the ministry through the dissemination of agricultural technical information to the rural communities with the aim of achieving the national development agenda through rural development in general and agricultural development in particular. Though some of these programmes have been successful, the Loan Schemes failed mainly due to institutional bureaucracy and failure to recover loans [11].

NGOs such as CARE international also carried out projects such as the Livingstone Food Security Project in collaboration with the Ministry of Agriculture and Livestock in south east Zambia (agro-ecological Zone I). The project piloted alternative extension models and had a series of participatory livelihood and needs assessment exercises. This also included the establishment of Village Management Committees (VMCs), to implement a seed loan scheme. These interventions have considerably been helpful to communities hit by successive droughts identify and prioritize their requirements. Working with the VMCs and farmer extension facilitators, the project achieved extensive coverage of farmers in its second and third seasons with only a small number of field staff. Collaboration with government extension service system also helped impart skills training in participatory assessment approaches and community institution-building to field staff from districts outside the immediate project area [11]. However, the project have not been effective in building resilience in food security as evidenced by the increasing hunger scenarios in the same areas from 2002-2009 which were only averted by food aid and relief services of the United Nations World Food Programme. Similarly, Christian based NGOs such as Catholic Relief Services, World Vision, and Lutheran World Federation have been active in both food aid and conservation farming training to hunger affected rural communities in many parts of Zambia. Broader farming systems and resource management skills training by these NGOs have been helpful to smallholder farmers in developing more resilient agriculture production systems. With the increasing participation of the private sector in agricultural extension, such projects could help demonstrate a partnership model which can be more sustainable for the future, both in Zambia and elsewhere.

\section{Study Area}

\section{Location and Climate}

Based on long term climatic data, Zambia is categorized into three agro-ecological zones, namely Zone I, IIa - b and III. Under normal climatic conditions, Zone I experiences annual mean precipitation of $<800 \mathrm{~mm}$ with annual mean temperatures of about $26.7^{\circ} \mathrm{C}$ and largely comprises the Luangwa-Zambezi rift valleys. Zone II experiences annual mean precipitation of between 800 to $1000 \mathrm{~mm}$ with annual mean temperatures of about $22.1^{\circ} \mathrm{C}$ and comprises the western semi-arid plains of the Zambezi Valley (IIb) and of Kafue Flood Plains, Southern and Eastern plateaus (IIa) and Luangwa Valley. Zone III experiences annual precipitation in the range of $1000 \leq 1500 \mathrm{~mm}$ and comprises the northern high rainfall area with moderate annual temperature means of about $21.7^{\circ} \mathrm{C}$. In this study, based on easy accessibility, six districts (two from each agro-ecological zone) were selected for the study. Gwembe and Siavonga (Zone I); Chibombo and Kapiri-mposhi (Zone II) and Lufwanyama and Mpongwe (Zone III). For details, see Figure 1.

In the farming seasons 2012/2013 and 2013/2014, Zambia experienced normal and good annual mean rainfall figures-ranging from 790 to 860 and $1450 \mathrm{~mm}$ in Zone I, II and III respectively [12]. In the 2013/14 farming season, the annual mean rainfall was slightly above normal; from 870 to 1200 and $1900 \mathrm{~mm}$ in Zone I, II and III respectively. Floods were experienced in some places in Zone II and III. In the year 2012/13, annual mean temperatures were within normal range: from $26^{\circ} \mathrm{C}, 23^{\circ} \mathrm{C}$ and $21^{\circ} \mathrm{C}$ in Zone I, II and III respectively as opposed to the period from $2009-2011$ when the mean annual temperatures were slightly higher than normal $\left(26^{\circ} \mathrm{C}\right.$ or $\left.27^{\circ} \mathrm{C}\right)$, especially in the Zone I where it was about $2^{\circ} \mathrm{C}$ higher, while Zone II and III had no significant differences from the normal [12]. There was no significant difference in annual mean temperature for 2013/14 period from the normal.

\section{Methodology}

\subsection{Household Survey}

A total of 210 small-holder farmers were sampled and interviewed (based on availability and gender), 70 from each agro-ecological zone, and 35 from each selected district community. Farmers' post-harvest survey on the 
Three agro ecological regions:

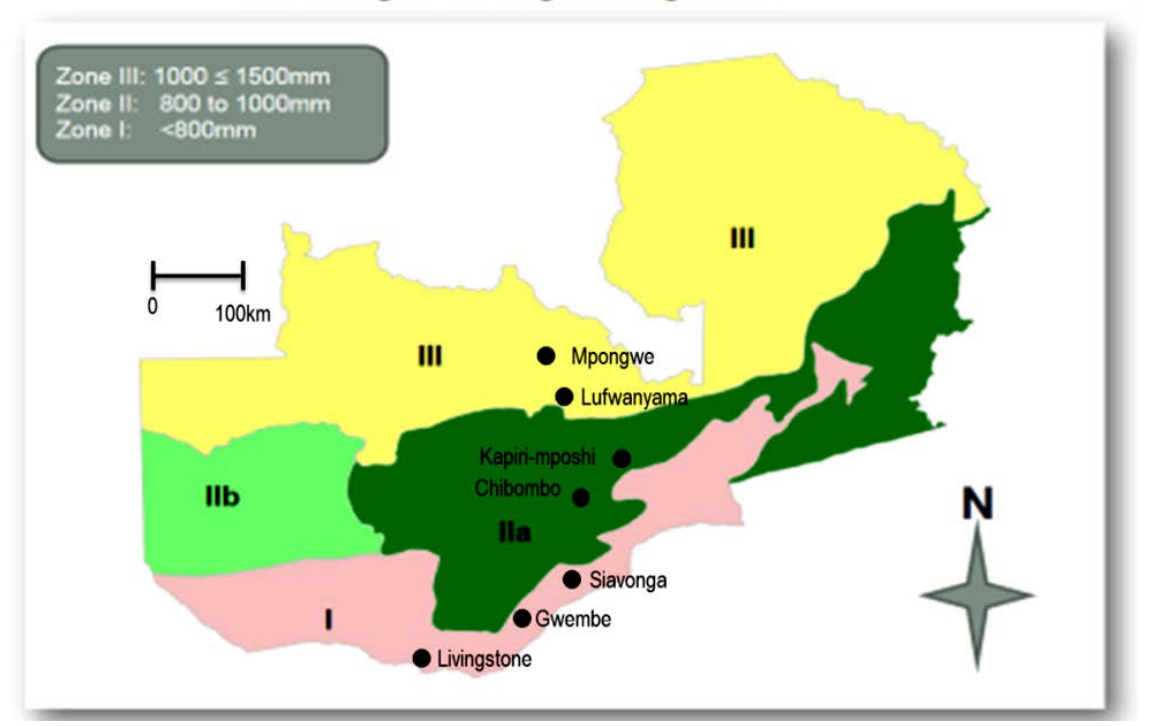

Figure 1. Zambia agro-ecological zones and study areas; adopted from [13].

yields of the main food crop (maize) was also conducted to establish levels of food availability and security in each of the sampled community. Indicators of adaptation were also investigated, and these were three-fold; namely, choice ofcrops (drought resistant, cash crop, or early maturating variety), and farming practices (crop rotation, agro-forestry/conservation) and crop mix or diversification. This study was conducted in the post-harvest period of June-July both for 2013, and 2014. Two assessments were made; the first one was in 2013, while the second assessment was done at the same time but in the following year, i.e., June and July of 2014. This was meant to obtain food crop yield data for two consecutive years and established indicative and meaning levels of food security in households in the study districts. In the second assessment, same households interviewed in the previous year were located and interviewed on their yield. All households (farmers) interviewed in the first phase were available and interviewed in the second phase.

Data was processed and analyzed using SPSS V16 software. Using this software, data (i.e., responses from interviews and staple food crop yields) were entered and organized on scale either as parametric (numeric, e.g., age of respondent, rainfall, temperature, amount of crop yields, house hold size etc.) or non-parametric (ordinal or coded, e.g., marital status, gender, adaptation status, farming method etc.) for each of the respondent. With many modeling options of this software, it is possible to process, obtain and display or visualize specific information such as frequency tables, graphs, correlations and test for levels of significance for data sets.

\subsection{Calculating Livelihood Vulnerability Index (LVI)}

For the purposes of this paper, only three main components (food, natural disaster/climate variability, and social demographics) were used. Each main component has sub-components, explanation, some questions or source of information and potential limitations (Table 1). The LVI was developed from literature, specifically from ideas in [14]-[21] using a balanced mean approach where sub-components contribute equality to the overall index even if each main component may have a different number of sub-components. The LVI formula uses the simple approach of applying equal weights to all components. However, because each of the sub-components may be measured with different scales, standardizing each sub-component to an index is required. The equation used for this purpose is adopted from the idea of Human Development Index:

$$
\text { Index }_{s_{d}}=\frac{S_{d}-S_{\min }}{S_{\text {max }}-S_{\text {min }}}
$$

where $S_{d}$ is the original sub-component for district $d$, and $S_{\min }$ and $S_{\max }$ are the minimum and maximum values respectively for each sub-component determined using data from all both community districts in each agroecological zone (Table 4 and Table 5). After each subcomponent was standardized using Equation (2) 
Table 1. Main components comprising vulnerability index after [14].

\begin{tabular}{cccc}
\hline $\begin{array}{c}\text { Main } \\
\text { components }\end{array}$ Sub-components & $\begin{array}{c}\text { Explanation of } \\
\text { sub-components }\end{array}$ & $\begin{array}{c}\text { Survey question } \\
\text { source }\end{array}$ & Source potential \\
\hline
\end{tabular}

Food

Percent of households that reported that they have not asked their local have you or someone their local government, government or NGO or NGO for assistance for any assistance in in the past 12 months. the past 12 months. in your family gone to your community leader for help?

Percent of households dependent on family farm for food.

Percentage of households primarily from their personal farms.

Where does your family get most of its food?

Does your family have adequate food the whole during the year that your family does not have enough food?

How many months a year does your family have problems getting enough food?

The inverse of (the number of crops grown

Average Crop Diversity Index (range: $>0-1)^{1}$.

What kind of crops does your household grow? that get their food year, or are there times by a household +1 ). e.g. A household that grows pumpkin, maize, beans, and cassava will have a Crop Diversity Index $=1 /(4+1)=0.20$.
Adapted from WHO/RBM (2003) in [14].

Developed for the purposes of this questionnaire.

Adapted from World Bank (1997) in [14].

Adapted from World Bank (1997) in [14].

Does your family save Percent of households Percentage of households that do not save crops/seed.

Percent of households that do not save seeds that do not save crops or seed from each harvest some of the crops you harvest to eat during a different time of year?

Percentage of households Does your family save that do not have seeds from year to year. seeds to grow the next year?

How many times has this area been affected

\section{Disasters} and Climate Variability
Average number of flood, or drought, events in the past 6 years (range: 0 - 7).
Total number of floods, droughts, and that were reported by households in the past 6 years. by a flood/drought in 2010-2013?
Percent of households Percentage of households that did not receive a warning about the pending natural disasters.

Percent of households with an injury or death as a result of the most severe natural disaster in the past 6 years. that did not receive a warning about the most severe flood, drought, event in the past 6 years.

Percentage of households that reported either an injury to or death of one of their family members as a result of the most severe flood or drought in the past 6 years.
Did you receive a warning about the flood/drought before it happened?

Was anyone in your family injured in the flood/drought? Did anyone in your family die during the flood/drought?
Developed for the purposes of this questionnaire.

Developed for the purposes of this questionnaire.

Adapted from Williamsburg Emergency Mgmt. (2004) in [14]. Household Natural Hazards Preparedness Questionnaire.

Adapted from Williamsburg Emergency Mgmt. (2004) in [14].

Developed for the purposes of this questionnaire.
Reliance on self-reported visits to government; Recall bias (more likely to remember going to government for dire issues).

Subjective
definition of "most".

Subjective definition of "struggle"; Reliance on self-reported number of months; May not reflect the overall trend of food scarcity (Respondents most likely to remember current year).

No specification regarding the seasonality of crops.

Does not count families that sell crops and save money.

No specification regarding the year in question.

Subjective definition of “warning”.

Recall bias (severe injuries are most likely to be remembered).

Recall bias (severe injuries are most likely to be remembered). 


\section{Continued}

\begin{tabular}{|c|c|c|c|c|c|}
\hline & $\begin{array}{l}\text { Mean standard } \\
\text { deviation of the daily } \\
\text { average maximum } \\
\text { temperature by month. }\end{array}$ & $\begin{array}{l}\text { Standard deviation of the } \\
\text { average daily maximum } \\
\text { temperature by month } \\
\text { between } 2010-2013 \text { was } \\
\text { averaged for each zone. }\end{array}$ & $\begin{array}{l}\text { 2010-2013: District } \\
\text { data; weather station } \\
\text { based in the study } \\
\text { area district. }\end{array}$ & $\begin{array}{l}\underline{\text { http://www.cpc.ncep.noa }} \\
\underline{\text { a.gov/products }}\end{array}$ & $\begin{array}{l}\text { Reliance on } \\
\text { average data; } \\
\text { Short time period. }\end{array}$ \\
\hline & $\begin{array}{l}\text { Mean standard } \\
\text { deviation of the daily } \\
\text { average minimum } \\
\text { temperature by month. }\end{array}$ & $\begin{array}{l}\text { Standard deviation of the } \\
\text { average daily minimum } \\
\text { temperature by month } \\
\text { between } 2010 \text {-2013 was } \\
\text { averaged for each zone. }\end{array}$ & $\begin{array}{l}\text { 2010-2013: District } \\
\text { data; weather station } \\
\text { based in the study } \\
\text { area district. }\end{array}$ & $\begin{array}{l}\underline{\text { http://www.cpc.ncep.noa }} \\
\underline{\text { a.gov/products }}\end{array}$ & $\begin{array}{l}\text { Reliance on average } \\
\text { data; Short time } \\
\text { period. }\end{array}$ \\
\hline & $\begin{array}{l}\text { Mean standard } \\
\text { deviation of average } \\
\text { precipitation } \\
\text { by month. }\end{array}$ & $\begin{array}{l}\text { Standard deviation of the } \\
\text { average monthly } \\
\text { precipitation between } \\
2010 \text {-2013 was averaged } \\
\text { for each province. }\end{array}$ & $\begin{array}{l}\text { 2010-2013: District } \\
\text { data; weather station } \\
\text { based in the study } \\
\text { area district. }\end{array}$ & $\begin{array}{l}\text { http://www.cpc.ncep.noa } \\
\underline{\text { a.gov/products }}\end{array}$ & $\begin{array}{l}\text { Reliance on } \\
\text { average data; } \\
\text { Short time period. }\end{array}$ \\
\hline \multirow[t]{4}{*}{$\begin{array}{l}\text { Social- } \\
\text { Demographics }\end{array}$} & $\begin{array}{l}\text { Percent of } \\
\text { households headed } \\
\text { by women. }\end{array}$ & Land ownership. & $\begin{array}{l}\text { 2010-2013: } \\
\text { District data. }\end{array}$ & $\begin{array}{l}\text { Government: } \\
\text { Community of } \\
\text { development a } \\
\text { social services. }\end{array}$ & $\begin{array}{l}\text { Reliance on average } \\
\text { data; Short time } \\
\text { period, data based } \\
\text { on sample only. }\end{array}$ \\
\hline & $\begin{array}{l}\text { Land tenure, access } \\
\text { to land ownership } \\
\text { by gender. }\end{array}$ & $\begin{array}{l}\text { Size and land tenure land } \\
\text { type: Inherited from } \\
\text { father or husband? }\end{array}$ & $\begin{array}{l}\text { 2010-2013: District } \\
\text { data and } \\
\text { questionnaire. }\end{array}$ & $\begin{array}{l}\text { Ministry of land; } \\
\text { Question developed } \\
\text { for the purposes of } \\
\text { this questionnaire. }\end{array}$ & $\begin{array}{l}\text { Reliance on } \\
\text { average data; Short } \\
\text { time period. }\end{array}$ \\
\hline & Crop yield. & Amount of yield. & $\begin{array}{l}\text { Estimates of yield, } \\
\text { physically and } \\
\text { questionnaire. }\end{array}$ & & $\begin{array}{l}\text { Subjectivity and } \\
\text { reliance on average } \\
\text { data; } \\
\text { Short time period. }\end{array}$ \\
\hline & $\begin{array}{l}\text { Access to Credit } \\
\text { Facilities by } \\
\text { gender (ratio). }\end{array}$ & $\begin{array}{l}\text { Have you borrowed } \\
\text { anything (money or } \\
\text { seed) towards farming } \\
\text { in the last } 6 \text { years. }\end{array}$ & $\begin{array}{l}\text { District data and } \\
\text { questionnaire. }\end{array}$ & $\begin{array}{l}\text { Government: } \\
\text { Community of } \\
\text { Development a social } \\
\text { services; and } \\
\text { questionnaire developed } \\
\text { for the purpose. }\end{array}$ & $\begin{array}{l}\text { Reliance on average } \\
\text { data; Short time } \\
\text { period, data based } \\
\text { on sample only. }\end{array}$ \\
\hline
\end{tabular}

(Table 5 for results) the sub-components were averaged to obtain the value of each main component [14].

$$
M_{d}=\frac{\sum_{i=1}^{n} \text { index } \cdot S_{d i}}{n}
$$

where $M_{d}=$ one of the main components for district $d$ [food, Livelihood Strategies (LS), Social Demographic Profile (SDP), and Natural Disasters and Climate Variability (NDCV)]. index $\cdot S_{d i}$ represents the sub-components, indexed by $i$, that make up each main component, while $n$ is the number of sub-components in each main component [14]-[16]. Once values for each of the main components for a given district communities were calculated, they were averaged using Equation (3) to obtain the district-level LVI [18]-[20]: Thus:

$$
\mathrm{LVI}_{d}=\frac{\sum_{i=1}^{3} W_{m i} \cdot M_{d i}}{\sum_{i=1}^{3} W_{m i}}
$$

where $\mathrm{LVI}_{d}$, the Livelihood Vulnerability Index for district $d$, equals the weighted average of the three major components. The weights of each major component, $W_{m i}$, were determined by the number of sub-components that make up each major component and are included to ensure that all sub components contribute equally to the overall LVI.

The following model can also be used 


$$
C F_{d}=\frac{\sum_{i=1}^{n} W_{m i} \cdot M_{d i}}{\sum_{i=1}^{n} W_{m i}}
$$

where $C F_{d}$ is an IPCC defined contributing factor (exposure, sensitivity, or adaptive capacity) for district $d, M_{d i}$ are the main components for district $d$ indexed by $i, W_{m i}$ is the weight of each main component, and $n$ is the number of main components in each contributing factor. Once exposure, sensitivity, and adaptive capacity were calculated, the three contributing factors were combined using the following equation:

$$
\text { LVI-IPCC }_{d}=\left(e_{d}-a_{d}\right) \times S_{d}
$$

where LVI-IPCC $_{d}$ is the LVI for a given district $d$ expressed using the IPCC vulnerability framework, and $e$ is the calculated exposure score for district $d$ (equivalent to the Natural Disaster and Climate Variability main component), and a is the calculated adaptive capacity score for district $d$ weighted average of the Livelihood Strategies (LS); $s$ is the calculated sensitivity score for district $d$ (weighted average of food main components). LVI-IPCC was scaled from -1 (least vulnerable) to 1 (most vulnerable) (Table 2).

\section{Results/Findings}

\subsection{Food Crop Production}

Food crop production in Zambia like in much of Sub-Saharan Africa is dominated by small-scale farmers who mainly practice rain-fed agriculture and are usually subsidized [22]. Subsidized inputs or input transfers are a social protection mechanism or intervention to boost production-based entitlements [23]. This approach is concerned with tackling vulnerability by raising yields and outputs in agriculture through the use of improved inputs, crop diversity, and enhanced cultivation practices. The agricultural extension system has been used for more than two decades to support small-holder farmers. According to [2], the role of national agricultural extension systems over the last thirty years in Zambia has been mainly to promote the high productivity through the hybrid programmes of staple food crops (especially maize) coupled with highly subsidized fertilizer distribution. The underlying assumption was that this would help solve the smallholder agriculture challenges and promote food security. However, increases in the frequency and severity of droughts (and floods in some instance) have continued to hit Zambia from the late 1980s and these have posed serious challenges for rain-fed dependent smallholder farmers. This probably, is just the beginning of the more severe challenges to come, as current climate change predictions for most tropical regions (of which Zambia lies) indicate a reduction in mean annual precipitation of about 20\% by 2050 [3] [4] [6] [12] [24]. In general, the extreme climatic events in form of droughts or floods which have already been experienced in many parts of the world over the last few decades are expected to intensify by the year 2050 [10] [25]-[27].

Confounding the climate change scenario over the last couple of decades in Zambia has been the economic structural adjustment and reform programmes (SAP) that eventually led to an infamous term "Highly Indebted Poor Countries" (HIPC). These economic structural adjustments as many critics have argued at length, have tended to increase poverty levels emanating from massive job losses, and the reduction in social spending in such key sectors as agriculture, health and education. Similarly, a series of droughts in the late 1980s to the early 1990s (with the removal of subsidies and reduced social spending to achieve HIPC completion point) left many smallholder farmers facing significant hardships [2]. In the process, small-holder rain dependent farmers have found themselves being forced to adapt their farming systems while the national agricultural extension system

Table 2. Categorization of main components into contributing factors using the IPCC framework (vulnerability definition for calculation the LVI-IPCC).

\begin{tabular}{cc}
\hline \multicolumn{2}{c}{ IPCC contributing factors to vulnerability main components } \\
\hline Exposure & Exposure natural disasters and climate variability \\
Adaptive capacity & Livelihood strategies \\
Sensitivity & Food
\end{tabular}


has found itself unable to meet this relatively sudden but huge demand. This has led to a growing self-inquiry by government about how the sector might be reformed in order to become relevant in an era in which it is increasingly important for government institutions to demonstrate effective performance for international financial support. In view of this, the Government of the Republic of Zambia formulated and launched a ten year National Agricultural Policy (2004-15) in 2005, and a four year National Agricultural Investment Plan (2014-18) under the Comprehensive Africa Agriculture Development Programme (CAADP) in 2013. Furthermore, the Zambia Six National Development Plan was revised in 2013 to reflect CAADP strategies of enhancing sustainable development and food security [28].

Consequently, and in line with the Zambian government's plans and policies on agricultural development, a Conservation Agriculture Scaling-Up (CASU) Project was officially launched on $4^{\text {th }}$ March 2014 by the Food and Agriculture Organization of the United Nations (FAO) in partnership with the Ministry of Agriculture and Livestock (MAL). The 4-year project (2013-2017)'s main focus is to contribute to reducing hunger, improve food security, nutrition and income for small and medium holder farmers while promoting sustainable use of natural resources. This project is implemented in 31 districts across 10 provinces of Zambia and is funded by European Union (EU) through the Tenth European Development Fund (EDF) costing about $€ 11 \mathrm{~m}$ and is jointly implemented by FAO and MAL. It is anticipated that a total of 21,000 Lead Farmers (LF) and an additional 315,000 Follower Farmers (FF) of which at least $40 \%$ are women will benefit from this initiative [28].

Under CASU, from the current 250,000, about 600,000 more small-holder farmers are targeted for conservation agriculture adoption by the year 2015. FAO's role in this project is to provide technical, logistical and operational support and serves as a liaison between MAL and various partners involved in Conservation Agricultural activities.

\subsection{Adaptation}

Results show that only $30 \%$ of the interviewed farmers were practicing some recommended adaptation farming approaches (i.e. practicing conservation farming combined with crop mix selection based on early maturing varieties drought resistant and intercropping). $70 \%$ were found not to practice any adaptation farming techniques (Figure 2). However, there were more farmers who had adopted drought resistant crops such as cotton, and cassava in agro-ecological Zone I, than in Zone II and III. The planting of drought resistant crops like cotton and cassava is an opportunity farmers can use to inter-crop with leguminous plants (e.g. cowpeas and groundnuts) and increase crop yield. This could contribute to the farmers' incomes.

Combined adaptation status in all the agro-ecological zones across gender are shown in Figure 2. Overall the results show that more women had adapted to changing climatic conditions than men. Adaptation indicators identified here included adoption of early maturing maize varieties, conservation farming methods, crop mix and rotation. However men on average had higher maize crop yields than women overall in spite of men not adopting new methods (Figure 2, Figure 3). This scenario may be attributed to traditional practices in which case women have no adequate access to livelihood assets like land, loans, ploughs and animal draft power. In most tribes in Zambia, women have less rights over land ownership than men, yet due to socio-cultural practices, it is women that have the responsibility over the daily welfare of the households in spite of little access to disposable income [9] [26].

\subsection{Gender Disparities}

Findings show that wide gender disparities do exist in all the three agro-ecological zones investigated. Women have no exclusive rights over land ownership. In all the three agro-ecological zones, it was found that women headed households had the lowest yield on average, yet most of the homes were found to be entirely headed by women, especially in Zone I where men were found to have either left in search of fertile land and enough rainfall further north and never returned (probably climate refugees) or had found an urban job, or have simply passed on. Findings have also shown that although there are fewer male headed households in agro-ecological Zone I (interviewed), overall, men's food crop yield was more than that of women in-spite the fact that men are almost half the number of women interviewed in the zone (Table 3). These findings are consistent with [9] observations: that although women are at the center of running homes in Africa, access to land ownership, and access to agricultural support services is still lagging behind and this makes women headed households more vulnerable to hunger and poverty than those headed by men (Tables 4-6). Difficulties in accessing land, markets and farm in-puts disadvantages the women headed households than those headed by men (Table 4). 


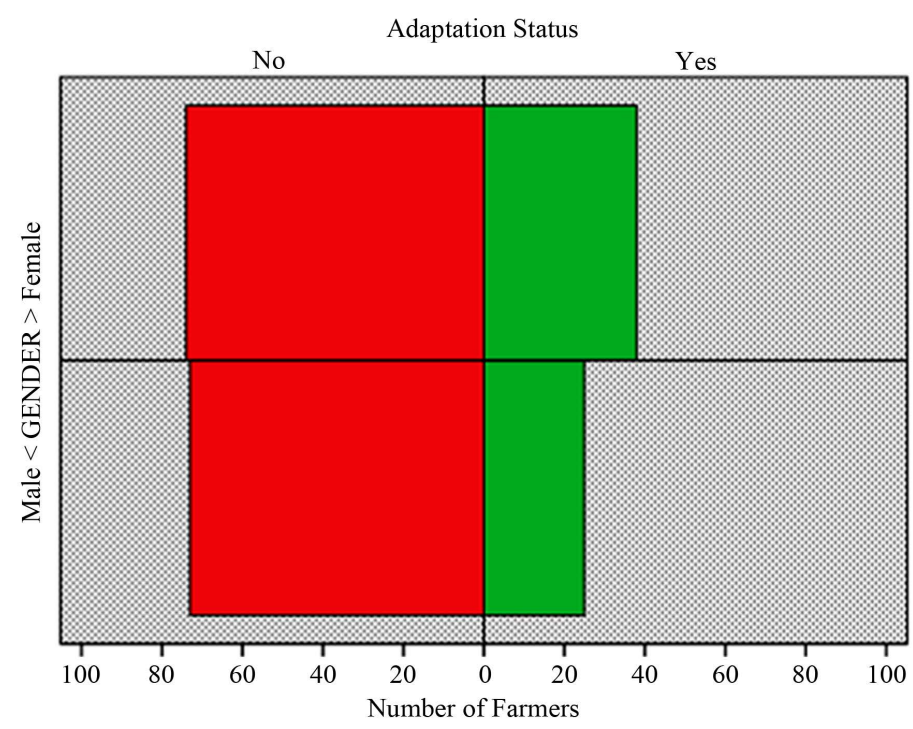

Figure 2. Adaptation status in all agro-ecological zones by gender.
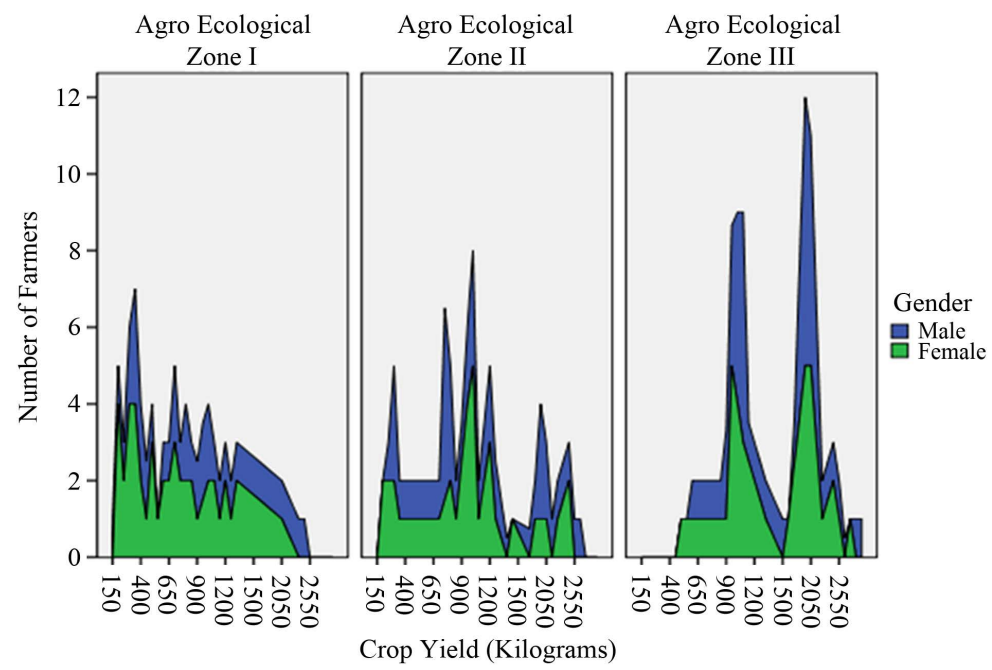

Figure 3. Average annual food crop yield by gender, per agro-ecological zone.

\subsection{Food Security}

Results have clearly shown that there are very few smallholder rain dependent farmers who yielded above 1.5 tonnes (one and half tonnes) in the period under investigation in all the agro-ecological zones except for Zone III (Figure 3). The food crop yield averages around one tonne while the distribution is skewed towards low food crop yield values (Figure 4).

Comparing with average households size which was found to be around 8 people per house, one tonne per year is not enough to see such a family size through to the next season. Basically, this means that there is food insecurity in Zambia as most households do not have access to adequate food throughout the year; or to last till the next harvest. The problem is more pronounced in agro-ecological Zone I than in II and III as shown in Tables 4-6.

\subsection{Market Access of Produces}

This was ranked by the interviewed as the biggest challenge confounding climate change adaptation among small-holder rain dependent farmers in Zambia. In the event farmers have harvested more than enough for their 
Table 3. Summary statistics (average yield per ecological zone by gender).

\begin{tabular}{|c|c|c|c|c|c|c|}
\hline Agro-ecological zone & Mean annual rainfall (mm) & Mean annual temp $\left({ }^{\circ} \mathrm{C}\right)$ & Gender & Mean crop yield & STD. deviation & $\mathrm{N}$ \\
\hline & & & Male & 798.08 & 533.569 & 26 \\
\hline \multirow[t]{3}{*}{ I } & $<800$ & 26.7 & Female & 668.18 & 401.174 & 44 \\
\hline & & & Total & 716.43 & 455.460 & 70 \\
\hline & & & Male & 1134.72 & 683.146 & 36 \\
\hline \multirow[t]{3}{*}{ II (a) and (b) } & 800 to 1000 & 22.8 & Female & 1054.41 & 627.811 & 34 \\
\hline & & & Total & 1095.71 & 653.349 & 70 \\
\hline & & & Male & 1640.28 & 620.002 & 36 \\
\hline \multirow[t]{5}{*}{ III } & $>1000$ & 21.7 & Female & 1455.88 & 647.462 & 34 \\
\hline & & & Total & 1550.71 & 635.684 & 70 \\
\hline & & & Male & 1231.12 & 704.496 & 98 \\
\hline & & & Female & 1024.55 & 641.683 & 112 \\
\hline & & & Grand total & 1120.95 & 678.014 & 210 \\
\hline
\end{tabular}

Table 4. Livelihood Vulnerability Index (LVI) sub-component values and minimum and maximum sub-component values for Zone I, II and III.

\begin{tabular}{|c|c|c|c|c|c|c|c|}
\hline $\begin{array}{c}\text { Main } \\
\text { Component }\end{array}$ & Sub-component & Units & $\begin{array}{c}\text { Zone } \\
\text { I }\end{array}$ & $\begin{array}{c}\text { Zone } \\
\text { II }\end{array}$ & $\begin{array}{l}\text { Zone } \\
\text { III }\end{array}$ & $\begin{array}{c}\text { Maximum } \\
\text { values in } \\
\text { all zones }\end{array}$ & $\begin{array}{c}\text { Minimum } \\
\text { values in } \\
\text { all zones }\end{array}$ \\
\hline \multirow{6}{*}{ Food } & Percent of households dependent solely on family farm for food. & Percent & 98 & 69 & 72 & 100 & 0 \\
\hline & Average number of months households struggle to find food. & $\begin{array}{l}\text { No. of } \\
\text { months }\end{array}$ & 7 & 5 & 4 & 12 & 0 \\
\hline & Average crop diversity index. & $1 / \mathrm{n}$ crops & 0.25 & 0.33 & 0.50 & 1 & 0.1 \\
\hline & Percent of households that do not save crops. & Percent & 9 & 11 & 13 & 100 & 0 \\
\hline & Percent of households that do not save seeds. & Percent & 28 & 58 & 34 & 100 & 0 \\
\hline & Average number of flood, drought events in the past 6 years. & Count & 4 & 3 & 3 & 6 & 0 \\
\hline \multirow{4}{*}{$\begin{array}{l}\text { Natural } \\
\text { Disaster/ } \\
\text { Climate } \\
\text { Change }\end{array}$} & $\begin{array}{l}\text { Percent of households that did not receive a warning } \\
\text { about the pending natural disasters. }\end{array}$ & Percent & 100 & 100 & 100 & 100 & 0 \\
\hline & $\begin{array}{l}\text { Mean standard deviation of monthly average of mean } \\
\text { maximum daily temperature (years: 2010-2013). }\end{array}$ & ${ }^{\circ} \mathrm{C}$ & 3.2 & 1.8 & 1.5 & 4.5 & 0.5 \\
\hline & $\begin{array}{l}\text { Mean standard deviation of monthly average of mean } \\
\text { minimum daily temperature (years: 2010-2013). }\end{array}$ & ${ }^{\circ} \mathrm{C}$ & 3.1 & 1.9 & 2.1 & 3.8 & 0.4 \\
\hline & $\begin{array}{l}\text { Mean standard deviation of monthly average precipitation } \\
\text { (years: 2010-2013). }\end{array}$ & $\mathrm{mm}$ & 70.2 & 49.9 & 49.3 & 230.8 & 6.5 \\
\hline \multirow{4}{*}{$\begin{array}{l}\text { Social- } \\
\text { Demo- } \\
\text { Graphics }\end{array}$} & Percent of households headed by women. & Percent & 62.7 & 50 & 48.5 & 100 & 0 \\
\hline & $\begin{array}{l}\text { Land tenure: Access to land ownership by gender } \\
\text { (women: men ratio). }\end{array}$ & Ratio & 0.25 & 0.31 & 0.35 & 1 & 0 \\
\hline & Crop yield. & Average & 716.43 & 1095.71 & 1550.71 & 2950 & 200 \\
\hline & Access to credit facilities by gender (women: men ratio). & Ratio & 0.14 & 0.15 & 0.19 & 1 & 0 \\
\hline
\end{tabular}


Table 5. Calculating for main components for LVI for all the agro-ecological zones.

\begin{tabular}{|c|c|c|c|c|}
\hline Main component & Sub-component & Zone I & Zone II & Zone III \\
\hline \multirow{6}{*}{ Food } & Percent of households dependent solely on family farm for food. & 0.980 & 0.690 & 0.720 \\
\hline & Average number of months households struggle to find food. & 0.583 & 0.417 & 0.333 \\
\hline & Average crop diversity index. & 0.167 & 0.256 & 0.444 \\
\hline & Percent of households that do not save crops. & 0.900 & 0.110 & 0.130 \\
\hline & Percent of households that do not save seeds. & 0.280 & 0.580 & 0.340 \\
\hline & Food Index ${ }^{\mathrm{a}}$ & 0.582 & 0.411 & 0.393 \\
\hline \multirow{5}{*}{$\begin{array}{c}\text { Natural } \\
\text { Disaster/ } \\
\text { Climate } \\
\text { Change }\end{array}$} & Average number of flood, drought events in the past 6 years. & 0.667 & 0.500 & 0.500 \\
\hline & $\begin{array}{l}\text { Percent of households that did not receive a warning about the pending natural } \\
\text { disasters. }\end{array}$ & 0.100 & 0.100 & 0.100 \\
\hline & $\begin{array}{l}\text { Mean standard deviation of monthly average of mean maximum daily temperature } \\
\text { (years: 2010-2013). }\end{array}$ & 0.675 & 0.325 & 0.250 \\
\hline & $\begin{array}{l}\text { Mean standard deviation of monthly average of mean minimum daily temperature } \\
\text { (years: 2010-2013). }\end{array}$ & 0.794 & 0.441 & 0.500 \\
\hline & Mean standard deviation of monthly average precipitation (years: 2010-2013). & 0.284 & 0.194 & 0.191 \\
\hline \multirow{6}{*}{$\begin{array}{c}\text { Social- } \\
\text { Demographics }\end{array}$} & Natural disaster/Climate Change Index ${ }^{a}$ & 0.504 & 0.312 & 0.308 \\
\hline & Percent of households headed by women. & 0.627 & 0.500 & 0.485 \\
\hline & Land tenure: Access to land ownership by gender (women: men ratio). & 0.250 & 0.310 & 0.350 \\
\hline & Crop yield. & 0.188 & 0.326 & 0.490 \\
\hline & Access to credit facilities by gender (women: men ratio). & 0.140 & 0.150 & 0.190 \\
\hline & Social-Demographics Index ${ }^{\mathrm{a}}$ & 0.301 & 0.322 & 0.379 \\
\hline
\end{tabular}

${ }^{\mathrm{a}}$ Using Equation (2); $\quad M_{d}=\frac{\sum_{i=1}^{n} \text { index } \cdot S_{d i}}{n}$.

Table 6. LVI-IPCC contributing factors calculation for Zones I, II, and III: after [21].

\begin{tabular}{|c|c|c|c|c|c|c|c|c|c|c|c|}
\hline \multirow{2}{*}{$\begin{array}{c}\text { IPCC } \\
\text { contributing } \\
\text { factors to } \\
\text { vulnerability }\end{array}$} & \multirow{2}{*}{$\begin{array}{l}\text { Main } \\
\text { component } \\
\text { values }\end{array}$} & \multirow{2}{*}{$\begin{array}{l}\text { Zone } \\
\text { I }\end{array}$} & \multirow{2}{*}{$\begin{array}{l}\text { Zone } \\
\text { II }\end{array}$} & \multirow{2}{*}{$\begin{array}{l}\text { Zone } \\
\text { III }\end{array}$} & \multirow{2}{*}{$\begin{array}{c}\text { No. of } \\
\text { subcomponents } \\
\text { per major } \\
\text { component }\end{array}$} & \multicolumn{3}{|c|}{ Contributing factor values } & \multicolumn{3}{|c|}{ LVI-IPCC values } \\
\hline & & & & & & Zone I & Zone II & Zone III & Zone I & Zone II & Zone III \\
\hline Exposure & $\begin{array}{l}\text { Natural disasters/ } \\
\text { climate change }\end{array}$ & 0.504 & 0.312 & 0.308 & 4 & 0.504 & 0.312 & 0.308 & & & \\
\hline $\begin{array}{l}\text { Adaptive } \\
\text { capacity }\end{array}$ & $\begin{array}{c}\text { Social demographic } \\
\text { Strategies; } \\
\text { Crop diversity }\end{array}$ & $\begin{array}{l}0.301 \\
0.250\end{array}$ & $\begin{array}{l}0.322 \\
0.330\end{array}$ & $\begin{array}{l}0.379 \\
0.500\end{array}$ & $\begin{array}{l}5 \\
3\end{array}$ & 0.281 & 0.325 & 0.567 & 0.149 & -0.0059 & -0.098 \\
\hline Sensitivity & $\begin{array}{c}\text { Food: } \\
\text { crop and seed storage }\end{array}$ & $\begin{array}{l}0.582 \\
0.900\end{array}$ & $\begin{array}{l}0.411 \\
0.580\end{array}$ & $\begin{array}{l}0.393 \\
0.340\end{array}$ & $\begin{array}{l}5 \\
2\end{array}$ & 0.672 & 0.459 & 0.378 & & & \\
\hline
\end{tabular}

consumption and want to sell the excess so that they can buy inputs for the next season, market accessibility has proved a serious challenge. In the end, farmers sell their maize at give-away prices to local businessmen who themselves sell to the millers in the cities at better price after the crop is graded and appropriately packaged. In some cases, some farmers have found themselves being swindled and not been paid for their maize "sold" to unscrupulous buyers. 


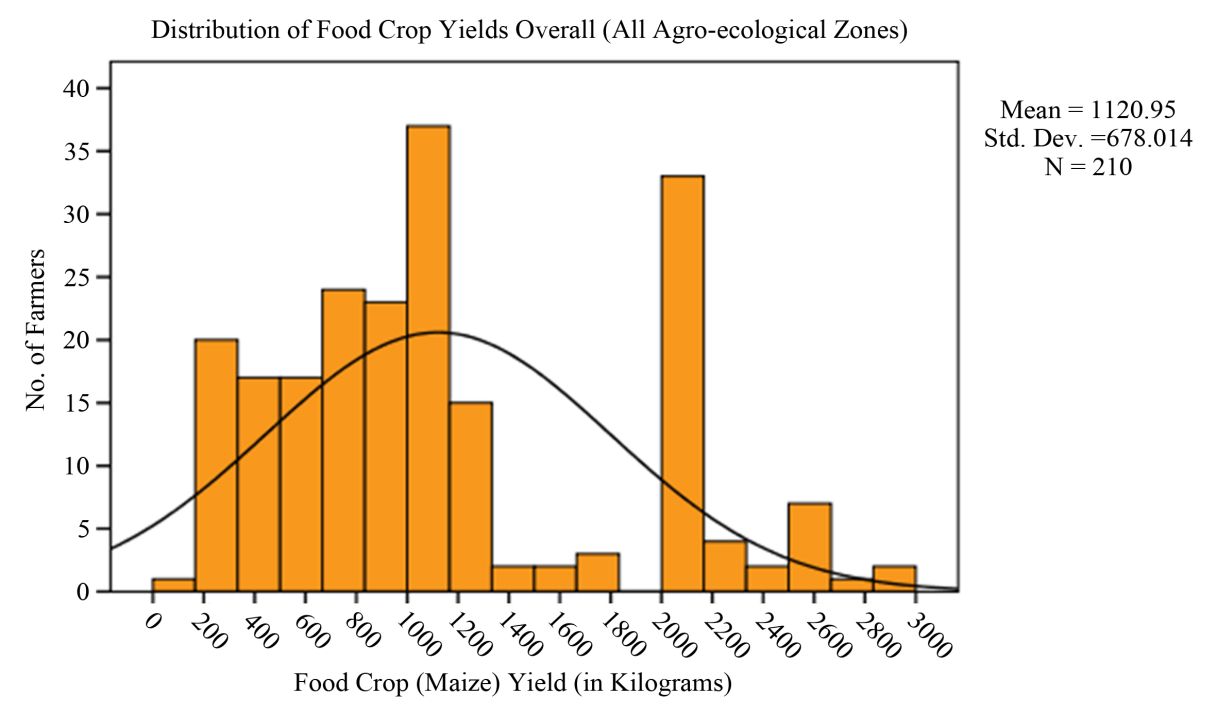

Figure 4. Food crop (maize) yields of rain fed small-holder farmers in Zambia.

\subsection{Poor Road Infrastructure}

Related to market access, findings show that poor road infrastructure has hindered movements and the flow of farm produces to markets, and in-put requirements such as seed and fertilizers to farmers. Most roads in study areas in agro-ecological Zone I and III are impassable and those that may be passable have been found to have poor bridges. This has tended to hinder rural farmers from accessing urban markets particularly in Gwembe. Instead, buyers have tended to follow rural farmers and end up determining the prices for the produce. Currently, with the focus on road upgrading under the Pave Zambia-2000 and Link Zambia-8000 Projects, many rural roads may receive some facelifts including bridges. This might facilitate the ease and speedy flow of fresh farm produce to markets and in-put resources to farmers.

\subsection{Fluctuating Market Prices}

This is one of the major setbacks to sustainable small-holding agriculture. Determined by market force-supply and demand, fluctuating market prices coupled with unstable local currency value are major hindering factors to sustainable agriculture in Zambia. Since rural farmers do not have effective safe storage facilities of their produce, coupled with poor post-harvest handling of their produce, maize is offloaded on the market by farmers at the same time, in which case supply surpasses demand. This lowers per unit cost of maize and farmers cannot recover the production costs in many instances. Findings have also established that in last three years, farmers have not determined the selling price cost of maize: Government through the Food Reserve Agency (FRA) and the millers who are the ultimate buyers determine the selling price. Also, due to poor storage and preservation of the maize yields by rural farmers, some of the stored maize usually goes bad before the turn of the year leaving most farmers vulnerable to hunger.

\subsection{Late Deliveries of Farming In-Puts}

Findings have revealed that late delivery of in-puts such as seed, fertilizers and chemicals confounded by poor road infrastructure (especially in the study districts in agro-ecological Zones I and III, Gwembe, Siavonga and Lufwanyama) makes it difficult for farmers to implement a sustainable agriculture business. Initial inputs such as seed and fertilizers are delivered late and when they are delivered, they are available at costs usually beyond the reach of an average rural farmer. Consequently, farmers cannot plan their planting season in good time.

\subsection{Deforestation}

The deforestation problem in Zambia is real though its distribution is marked with differing magnitudes. Due to poor soils that are increasingly becoming acidic and underlain with a hard-pan, cutting down trees in forests for 
agricultural land by local people is common practice. Although quantitative estimations on the rate of forest cover loss is beyond this paper, observations revealed that trees in agro-ecological Zone I are being wiped out at a faster rate, contrary to the global level deforestation rates which according to [29], have reduced. With low rainfall pattern in this zone, poor regeneration of trees is evident and chances that this zone turns into an arid environment within the next 30 years are high. According to [13] Agro-ecological zone is slowly expanding northwards into agro-ecological Zone II, mainly due to forest depletion for agricultural land, coupled with changing climatic conditions. Findings revealed that some small-scale farmers originally from agro-ecological Zone I, have migrated and are now farming in agro-ecological Zone II and III. These climate refugees are looking for fertile land with enough rainfall and may be contributing to the expanding deforestation practice for farmland in Zones II and III. Deforestation lowers carbon sink and provides a negative feedback to climate change.

\subsection{Livelihood Vulnerability}

The meaning of livelihood vulnerability being referred to in this paper is limited to the inability of rain dependent small-holder farmers to produce enough to satisfy their family's food consumption needs. Vulnerability is a concept that has been used in different research traditions and originates from natural hazards and disaster studies in geography. Depending on the research area, it has been applied exclusively to the societal subsystem, to the ecological, natural, or biophysical subsystem. Vulnerability is most often conceptualized as being constituted by components that include exposure to perturbations or external stresses, sensitivity to perturbation, and the capacity to adapt. Like resilience, vulnerability is generally viewed as being specific to perturbations that impinge on the system [30].

As evidenced by the results (Tables 4-6), agro-ecological Zone I is the most highly vulnerable to climate change risks, with a Livelihood Vulnerability Index (LVI) of 0.149 , followed by Zone III and Zone II with LVIs of -0.098 and -0.0059 respectively. However, the latter two zones are not as vulnerable as initially believed. These yielded negative LVIs. LVI-IPCC scales from -1 (least vulnerable) to 1 (most vulnerable). However, the reasons for such a level of vulnerability in Zone I may be explained by low rainfall, as well as poor road infrastructure which indirectly influencesaccessibility to farm in-puts and market for farm produces. Zone II being close to the line of rail, is the least vulnerable among the zones and have easy accessto in-puts, markets while probably engaging in other livelihood activities i.e. diversification of livelihood activities.

Using Equation (1), for calculating LVI from sub components for Food, Natural Disaster/Climate Change and Social Demographic profiles, Table 5 displays the results.

Using Equation (5), i.e.: LVI-IPCC $_{d}=\left(e_{d}-a_{d}\right) \times S_{d}$ : overall vulnerability for each zone was calculated and the results are displayed (Table 6).

\section{Conclusions}

Following the evaluation of scenarios including staple food crop yields (maize), it is correct to conclude that most rain-dependent small-holder farmers in Zambia are facing considerable hardships in adapting to the changing climate. The main hardship being faced bordered on accessing markets, poor road infrastructure, fluctuating market prices, animal disease, high costs and late deliveries of farming in-puts. Food insecurity does exist in the studied areas and that this was far worse in Zone I than Zone II and III (Tables 4-6). Food insecurity disparities across households based on gender are also evident. The female gender headed households were found to be more vulnerable than those headed by the opposite gender. While efforts by government have been made to assist farmers towards adaptation for food security through extension projects, there are still some challenges to achieve desired outcomes as evident in this study. Many farmers are still unable to afford certain alternatives such as agro-forestry or conservation farming techniques. Animal diseases (especially foot and mouth on cattle and swine fever on pigs) and lack of access to systematic and timely veterinary support has made animal raring difficult especially in agro-ecological Zone I. Restocking and disease resistant animals such as donkeys have been distributed but donkeys have been rejected in agro-ecological Zone I. This is because the people in this zone culturally value cattle more than any other animal: a herd of cattle is considered to be a symbol of great wealth.

Conversely, difficulties in accessing markets, poor road infrastructure, fluctuating market prices, high costs and late deliveries of farming in-puts are confounding challenges farmers are facing in all the agro-ecological 
zones. Similarly, because of gender-based inequalities in accessing critical livelihood assets (e.g. land, credit, technology, information and market), findings have clearly shown that women are less likely to recover from the effects of climate change risks. Since women manage most rural households, especially in Zone I, their lack of access to livelihood assets and credit facilities weaken capacity to adapt to climate change risks. This confounds the existing challenges in food security, poverty reduction and environmental protection. These findings are consistent with much of the literature on the vulnerability of women to climate change e.g. [9] [10] [24] [31]. However, although in their early stages, programmes to facilitate access to credit and land ownership by women have been introduced by NGOs and Ministry of Community Development, Mother and Child Health. Nevertheless, it is clear, that changes in climatic conditions can scale up massive sufferings from hunger, malnutrition, disease and extreme poverty in rural communities, because these people generally lack the necessary adaptive capacities to cope with even slight changes in climate.

As evidenced by the findings in this study, the focus of many agricultural extension programmes in Zambia has mainly been to increase yield, assuming that climatic conditions would remain favorable. Thus, the observation made by [32] was found to be correct: that most past and current adaptations efforts to climate variability and extremes, have tended to focus more on reactive adaptation (to climate change as it occurs), rather than anticipatory or planned adaptation (to reduce vulnerability to future climate change). For example, disaster management preparedness and early warning systems do not exist in Zambia, but only come into being after a disaster has occurred. There is critical lack of preparedness in Zambia. As argued by [33] building adaptation and resilience to climate change for agrarian communities is very important for sustainable rural development. That is why governments and concerned non-government organizations must work together and take a quick and board action and revalue the small-scale farming enterprise as critical to environmental, social-cultural and economic well-being for sustainable rural development. This must be the defining triple-bottom-line approach to building climate change resilience. [34] extends this argument; that farmers across the world need to undertake continual adjustments to their properties' physical capital, productive capacity and output, to adapt to an uncertain future climate. This is particularly important to farmers in drought hit zones with rapid social changes such as that of Zambia's agro-ecological Zone I.

\section{Acknowledgements}

Special thanks to all our friends, the small-holder rain dependent farmers in Gwembe, Siavonga, Chibombo, Kapiri, Mpongwe and Lufwanyama for their cooperation, and those who facilitated the accomplishment of this work. A special thanks to the Ministry of Agriculture and Livestock rural offices in study areas for their support.

\section{References}

[1] CSO (Central Statistical Office of Zambia) (2010) Census Report of 2010, GRZ.

[2] FAO (Food and Agricultural Organization) (2010) Country Profile. http://www.fao.org/isfp/country-information/zambia/en/

[3] Malhi, Y. and Wright, J. (2004) Spatial Patterns and Recent Trends in the Climate of Tropical Forest Regions. Philosophical Transactions of the Royal Society B, 359, 311-329. http://dx.doi.org/10.1098/rstb.2003.1433

[4] Sithole, A. and Murewi, F.J.C. (2009) Climate Variability and Change over Southern Africa: Impacts and Challenges. African Journal of Ecology, 47, 17-20. http://dx.doi.org/10.1111/j.1365-2028.2008.01045.x

[5] Wheeler, D. (2011) Quantifying Vulnerability to Climate Change: Implications for Adaptation Assistance. Center for Global Development, Working Paper 240.

[6] IPCC (2007) Climate Change: Impacts, Adaptation and Vulnerability. Contribution of Working Group II to the Fourth Assessment Report of the Intergovernmental Panel on Climate Change. Cambridge University Press, Cambridge, 433-467.

[7] International Institute for Sustainable Development (2013) Follow-Up to the Development Agenda beyond 2015 and Rio+20. IISD, Winnipeg.

[8] Stocker, T.F., Qin, D., Plattner, G.-K., Alexander, L.V., Allen, S.K., Bindoff, N.L., Bréon, F.-M., Church, J.A., Cubasch, U., Emori, S., Forster, P., Friedlingstein, P., Gillett, N., Gregory, J.M., Hartmann, D.L., Jansen, E., Kirtman, B., Knutti, R., Krishna Kumar, K., Lemke, P., Marotzke, J., Masson-Delmotte, V., Meehl, G.A., Mokhov, I.I., Piao, S., Ramaswamy, V., Randall, D., Rhein, M., Rojas, M., Sabine, C., Shindell, D., Talley, L.D., Vaughan, D.G. and Xie, S.-P. (2013) Technical Summary. In: Stocker, T.F., Qin, D., Plattner, G.-K., Tignor, M., Allen, S.K., Doschung, J., 
Nauels, A., Xia, Y., Bex, V. and Midgley, P.M., Eds., Climate Change 2013: The Physical Science Basis. Contribution of Working Group I to the Fifth Assessment Report of the Intergovernmental Panel on Climate Change, Cambridge University Press, Cambridge, 33-115.

[9] World Bank (2009) Awakening Africa’s Sleeping Giant: Prospects for Commercial Agriculture in Guinea Savannah Zone. Agriculture and Rural Development, Washington DC, 218.

[10] OECD (Organization for Economic Corporation and Development) (2011) Environmental Outlook to 2050 Report.

[11] Mitti, G.M.D. and Kalonge, S. (1997) Experimenting with Agricultural Extensions in Zambia: Care’s Livingstone Food Security Project Report.

[12] NOAA (2014) Climate Prediction Center. http://www.cpc.ncep.noaa.gov/products/JAWF Monitoring/South Africa/index.shtml

[13] ZEMA (2012) Zambia Environmental Management Atlas of Our Changing Environment, GRID-Erendal/UNEP.

[14] Hahn, M.B., Riederer, A.M. and Foster, S.O. (2009) The Livelihood Vulnerability Index: A Pragmatic Approach to Assessing Risks from Climate Variability and Change-A Case Study in Mozambique. Global Environmental Change, 19, 74-88. http://dx.doi.org/10.1016/j.gloenvcha.2008.11.002

[15] Smit, B. and Wandel, J. (2006) Adaptation, Adaptive Capacity and Vulnerability. Global Environmental Change, 16, 282-292. http://dx.doi.org/10.1016/j.gloenvcha.2006.03.008

[16] Füssel, H.-M. (2007) Vulnerability: A Generally Applicable Conceptual Framework for Climate Change Research. Global Environmental Change, 17, 155-167. http://dx.doi.org/10.1016/j.gloenvcha.2006.05.002

[17] Füssel, H.-M. (2009) Development and Climate Change: Review and Quantitative Analysis of Indices of Climate Change Exposure, Adaptive Capacity, Sensitivity and Impacts. World Bank, Washington DC.

[18] Reed, M.S., Podesta, G., Fazey, I., Geeson, N., Hessel, R., Hubacek, K., Letson, D., Nainggolan, D., Prell, C., Rickenbach, M.G., Ritsema, C., Schwilch, G., Stringer, L.C. and Thomas, A.D. (2013) Combining Analytical Frameworks to Assess Livelihood Vulnerability to Climate Change and Analyze Adaptation Options. Ecological Economics, 94, 66-77. http://dx.doi.org/10.1016/j.ecolecon.2013.07.007

[19] Williamson, T., Hessel, H. and Mark, J. (2012) Adaptive Capacity Deficits and Adaptive Capacity of Economic Systems in Climate Change Vulnerability Assessment. Forest Policy and Economics, 15, 160-166. http://dx.doi.org/10.1016/j.forpol.2010.04.003

[20] Engle, N.L. (2011) Adaptive Capacity and Its Assessment. Global Environmental Change, 21, 647-656. http://dx.doi.org/10.1016/j.gloenvcha.2011.01.019

[21] IPCC (2001) Climate Change 2001: Impacts, Adaptation, and Vulnerability, Contribution of Working Group II to the Third Assessment Report. Cambridge University Press, Cambridge.

[22] Parry, M.L, Rosenzweig, C., Iglesias, A., Livermored, M. and Fischere, G. (2004) Effects of Climate Change on Global Food Production under SRES Emissions and Socio-Economic Scenarios. Global Environmental Change, 14, 53-67. http://dx.doi.org/10.1016/j.gloenvcha.2003.10.008

[23] Kodamaya, S. (2011) Agricultural Policies and Food Security of Smallholder Farmers in Zambia. African Study Monographs, 42, 19-39.

[24] The Royal Society (2012) People and the Planet. The Royal Society Science Policy Centre Report 01/12.

[25] Nicholson, E.S. (2001) Climatic and Environmental Change in Africa during the Last Two Centuries. Climate Change, 17, 123-144.

[26] International Panel for Sustainable Resource Management, IPSRM (2010) Marrakech Process and Green Economy Initiative: Working towards a Sustainable Consumption and Production for a Green Economy, UNEP.

[27] Reid, W.V., Chen, D., Goldfarb, L., Hackmann, H., Lee, Y.T., Mokhele, K., Ostrom, E., Raivio, K., Rockstro, J., Schellnhuber, H.J. and Whyte, A. (2012) Earth System Science for Global Sustainability: Grand Challenges. Science, 330, 916-917.

[28] Food and Agricultural Organization (2014) Zambia, EU, and FAO Launch Conservation Agriculture Project. http://www.fao.org/africa/news/detail-news/en/c/215584/

[29] FAO (2013) Statistical Year Book 2013, FAO.

[30] Gallopin, G.C. (2006) Linkages between Vulnerability, Resilience, and Adaptive Capacity. Global Environmental Change, 16, 293-303. http://dx.doi.org/10.1016/j.gloenvcha.2006.02.004

[31] Bryan, E., Ringler, C., Okoba, B., Roncoli, C., Silvestri, S. and Herrero, M. (2013) Adapting Agriculture to Climate Change in Kenya: Household Strategies and Determinants. Journal of Environmental Management, 114, 26-35. http://dx.doi.org/10.1016/j.jenvman.2012.10.036

[32] Schneider, S.H., Easterling, W.E. and Mearns, L.O. (2000) Adaptation: Sensitivity to Natural Variability, Agent As- 
sumptions and Dynamic Climate Changes. Climatic Change, 45, 203-221.

http://dx.doi.org/10.1023/A:1005657421149

[33] Kiem, A.S. and Austin, E.K. (2013) Drought and the Future of Rural Communities: Opportunities and Challenges for Climate Change Adaptation in Regional Victoria, Australia. Global Environmental Change, 23, 1307-1316.

http://dx.doi.org/10.1016/j.gloenvcha.2013.06.003

[34] Wheeler, S., Zuo, A. and Bjornlund, H. (2013) Farmers' Climate Change Beliefs and Adaptation Strategies for a Water Scarce Future in Australia. Global Environmental Change, 23, 537-547. http://dx.doi.org/10.1016/j.gloenvcha.2012.11.008 
Scientific Research Publishing (SCIRP) is one of the largest Open Access journal publishers. It is currently publishing more than 200 open access, online, peer-reviewed journals covering a wide range of academic disciplines. SCIRP serves the worldwide academic communities and contributes to the progress and application of science with its publication.

Other selected journals from SCIRP are listed as below. Submit your manuscript to us via either submit@scirp.org or Online Submission Portal.
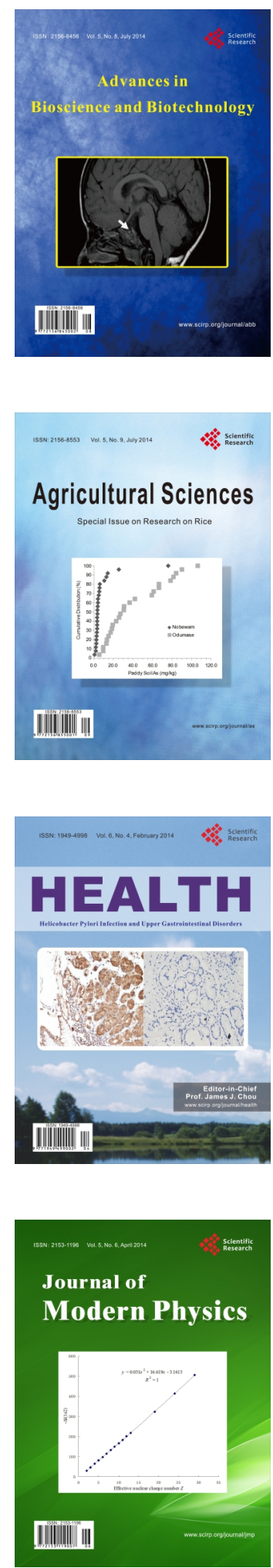
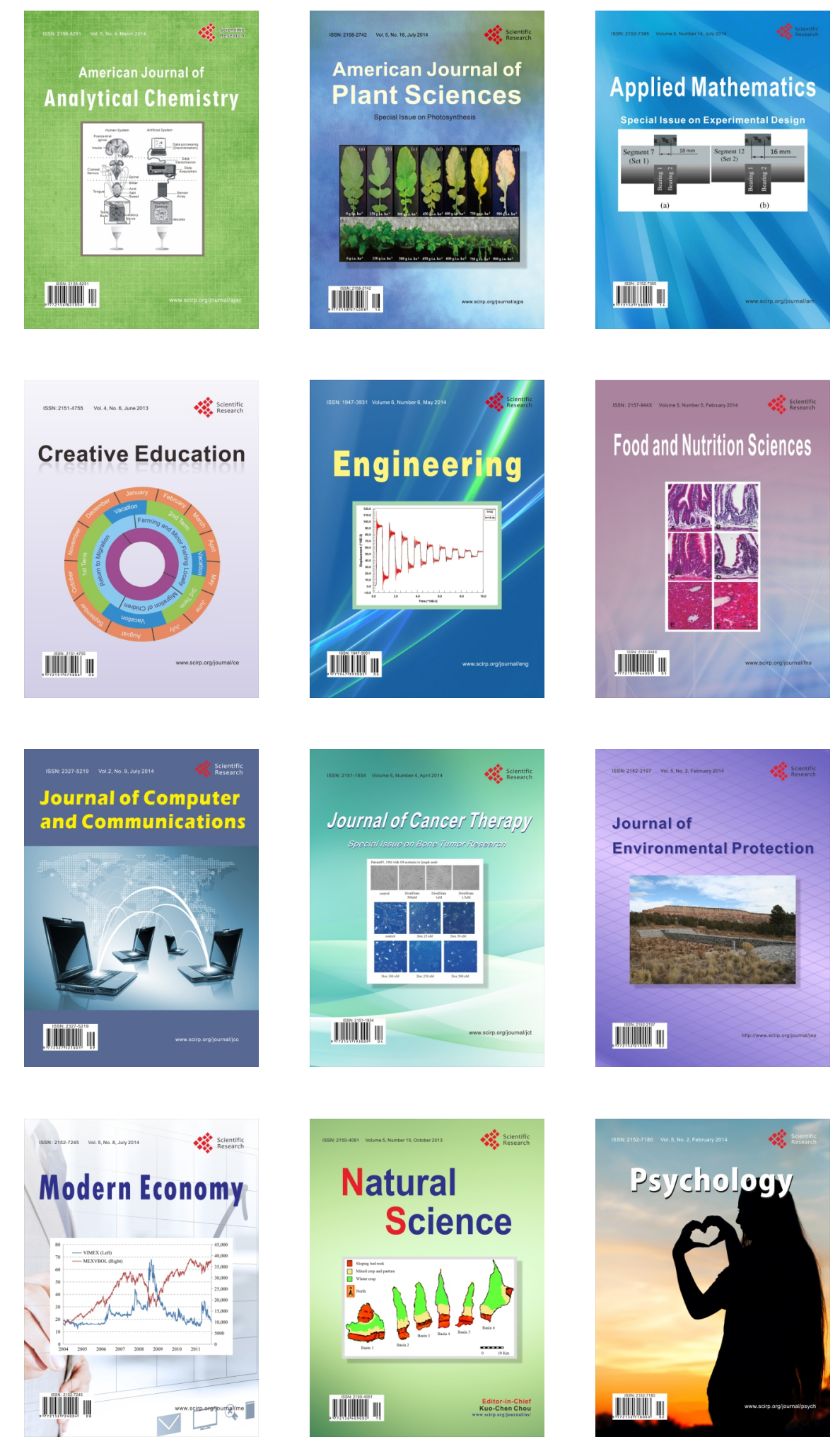